\title{
The Democratic Constitution: Why Europeans Should Avoid American Style Constitutional Judicial Review ${ }^{1}$
}

\author{
Richard Bellamy \\ Department of Political Science \\ University College London, London WC1H 9QU \\ UK \\ email: r.bellamy@ucl.ac.uk \\ tel: $+44(0) 2076794980$ \\ fax: +44(0) 2076794969
}

\begin{abstract}
Understanding of the relationship between constitutionalism and democracy among legal and political philosophers reflects an idealised account of the US constitution and the nature of judicial review. This view is normatively and empirically flawed. The US constitution is built on pre-democratic assumptions and its countermajoritarian checks and balances are largely regressive, benefiting privileged minorities over the underprivileged. By contrast, 'actually existing democracy', involving competing parties and majority rule, is constitutional in its process and effects, treating all with equal concern and respect, upholding rights and maintaining the rule of law. Judicial review undermines these beneficial qualities.
\end{abstract}

Key words Democracy, constitutions, judicial review, rights 
Running head: The democratic constitution

Does democracy need a constitution? The increasingly dominant view is that it does. Constitutions are said to enshrine and secure the rights central to a democratic society. According to this account, a constitution is a written document, superior to ordinary legislation and entrenched against legislative change, justiciable and constitutive of the legal and political system (Raz, 1998: 153-4). It is the constitution, not participation in democratic politics per se, that offers the basis for citizens to be treated in a democratic way as deserving of equal concern and respect (Dworkin, 1996: 24, 32-35). The electorate and politicians may engage in a democratic process, but they do not always embrace democratic values. The defence of these belongs to the constitution and its judicial guardians. This view has been neatly summarised by Cherie Booth, speaking as a distinguished QC rather than the wife of Tony Blair. As she puts it:

'In a human rights world ... responsibility for a value-based substantive commitment to democracy rests in large part on judges ... [J]udges in constitutional democracies are set aside as the guardians of individual rights ... [and] afforded the opportunity and duty to do justice for all citizens by reliance on universal standards of decency and humaneness ... in a way that teaches citizens and government about the ethical responsibilities of being participants in a true democracy' (Booth, 2005). 
I believe both the concern over democracy and the proposed remedy to be largely misconceived. The one overlooks the constitutional role and achievements of democratic politics, while the other places an impossible task upon the judiciary. To a large degree, the misconceptions about both constitutionalism and democracy underlying this mistaken analysis stem from the idealisation of the Constitution of the United States by distinguished American legal and political philosophers, especially those who reached intellectual maturity during the Warren Court era of the 1960s. Yet, in certain crucial respects its design and rationale is pre-democratic and of doubtful legitimacy in a democratic age. As I shall show below, once we appreciate the constitutionality of actually existing democratic processes then the justification for its constitutional restriction by American style judicial review largely falls.

\section{CONSTITUTIONALISM AND THE US CONSTITUTION}

The US Constitution can make a good claim to be the first modern constitution, while its longevity has made it a model for many of the ways we think about the role and very form of a constitution. However, it is a complex document that contains two not entirely compatible conceptions of constitutionalism - the legal and the political - both of which it partly conceives in pre-modern terms.

Most written constitutions contain two elements, the US constitution included.

The first element consists of an enumeration of basic rights that are held to constitute the fundamental law of the polity and with which no ordinary pieces of legislation or executive acts must conflict. The second element - often the greater part - is given over to a detailed description of the political and legal system, setting out the electoral rules, 
enumerating the powers and functions of different levels and agencies of government, and so on. The American constitution initially consisted of this second element alone, with the Bill of Rights added later as a series of amendments. However, as the quotation from Cheri Booth indicates, constitutionalism is increasingly identified with the first element - a Bill of Rights - and read as defining the political morality of a democratic society that upholds the necessary requirements for all citizens to be treated with equal concern and respect. As such, it has become the basis for the contemporary legal constitutionalist approach of rights-based judicial review.

Legal theorists tend to regard the second element of the constitution as 'nominal', being of little weight unless read through the first (Raz, 1998: 153; Sartori, 1962: 861). After all, a dictatorship could have a constitution in the sense of a description of the organs of government. True, a school of thought does exist that argues that we should read the first, rights element, merely as a guide to understanding the second, system of politics element (Ely, 1980). In other words, we should see rights as indicating what a political process that treats citizens with equal concern and respect should be like, rather than as what a democratic legislative outcome should contain. However, the difficulty with this argument is that there will be a tendency to make the perceived fairness of the outcome the guide to the fairness of the process that gave rise to it, so that the two approaches become indistinguishable. Moreover, it too makes the judiciary rather than citizens the guardians of the democratic constitution and so collapses into legal constitutionalism..

Instead, I wish to argue that we should see the second element as belonging to an older and alternative tradition of political constitutionalism (Bellamy, 1996; 2007: Part 2, 
Morris-Jones, 1965; Maddox, 1982). This tradition sees the political system itself, not its legal description in a written constitution but its actual functioning, as the true and effective constitution. The political constitutionalist tradition took the metaphor of the body politic seriously. Just as a healthy human body depended on a good constitution and a balanced way of life, so it was claimed a healthy polity required its constituent parts to be in balance. The problem was that this view of the constitution also predates modern democratic societies. And although slavery to one side, the American constitution is premised on the democratic principle of equality, the founders were ignorant of the workings of mass democracies and somewhat apprehensive about their emergence. So the system they advocated was largely premised on what they feared would be democracy's chief drawbacks, in particular 'majority tyranny' and factionalism. However, in so doing they overlooked the constitutive importance of majority rule as the embodiment of political equality, on the one hand, and the constitutional role of the balance between competing parties, on the other. It is these two qualities of the twenty-two or so established working democracies that lend them their constitutional quality and form the basis of a contemporary political constitutionalism.

\section{DEMOCRACY AND POLITICAL CONSTITUTIONALISM}

Why should we adopt a democratic form of political constitutionalism? The justification for such an approach rests on three key claims (Waldron, 1999; Bellamy, 2007). The first is that we reasonably disagree about the substantive outcomes that a society committed to the democratic ideals of equality of concern and respect should achieve. The second is that the democratic process is more legitimate than the judicial process at resolving these 
disagreements. The third is that it is also an effective mechanism for upholding the key constitutional goods of individual rights and the rule of law. I shall explore the first two claims in this section and the third in the next.

The desire to articulate a coherent and normatively attractive vision of a just and well-ordered society is a noble and important endeavour. But though all who engage in this activity aspire to convince others of the truth of their own position, none has so far come close to succeeding. Rival views by similarly competent theorists continue to proliferate, their disagreements both reflecting and occasionally informing the political disagreements between ordinary citizens over every conceivable issue from tax policy to health care. The fact of disagreement does not indicate that no theories of justice are true. Nor does it mean that a democratic society does not involve a commitment to rights and equality. It does show, though, that there are limitations to our ability to identify a true theory of rights and equality and so to convince others of its truth. John Rawls has associated these limitations with the 'burdens of judgement' (Rawls, 1993: 55-7). Even the best argued case can meet with reasonable dissent due to such factors as the complex nature of much factual information and uncertainty over its bearing on any case, disagreement about the weighting of values, the vagueness of concepts, the diverse backgrounds and experiences of different people, and the variety of normative considerations involved in any issue and the difficulty of making an overall assessment of their relative weight. Such difficulties are likely to be multiplied several fold when it comes to devising policies that will promote our favoured ideal of democratic justice. In part, the problem arises from the complexity of cause and effect in social and economic life, so that it will be hard to judge what the consequences of any given measure will be. 
But as well as the difficulty of specifying what policies will bring about given values, disagreements about the nature of these values also mean it will be difficult to identify those political, social and economic conditions that best realise them. For example, both types of difficulty are in evidence when philosophers or citizens debate the degree to which markets arrangements are just or the modifications that might be necessary to render them so. How far they can or should reflect people's efforts, entitlements or merits, say, are all deeply disputed for reasons that are both normative and empirical. If there are reasonable disagreements about justice and its implications, then it becomes implausible to regard constitutional courts as basing their decisions on the 'correct' view of what democratic justice demands in particular circumstances. At best, their superior position must rest on their providing a more conscientious and better informed arbitration of the disagreements and conflicts surrounding rights and equality than democratic politics can offer. Courts can obviously make a good claim to offer a fair and impartial process for resolving disputes, where all are treated as equals. But, when it comes to making decisions about our collective life, as constitutional courts implicitly do when they strike down legislative or executive measures or decide test cases, they lack the intrinsic fairness and impartiality of the democratic process - that of treating each person's views equally. They restrict access and unduly narrow the range of arguments and remedies that may be considered, and are neither accountable nor responsive to citizens in ways that ensure their opinions and interests receive equal concern and respect. Litigation is a time consuming business, with constitutional courts perforce having to be highly selective as to which cases they hear. When they do so, the case is presented as a dispute between two litigants and the only persons and arguments with 
standing have to relate to the points of law that have been raised by those concerned.

Such legalism is vital in what one might call the 'normal' judicial process, being

intimately linked to the rule of law in the formal sense of rule by known and consistently interpreted laws. But it is inappropriate for determining the bearing of fundamental political principles on the collective life of the community. In this sort of decision, the limits imposed by the legal process risk excluding important considerations in ways that may be arbitrary so far as the general issues raised by a case are concerned. Restricted access to and standing before the court, means not all potentially relevant concerns have an equally fair chance of being presented. Most importantly, it is the judges who decide. Yet, they also disagree. They differ over the relevance and interpretation of the law, the weight of different moral values, the empirical evidence - indeed, all the factors that produce principled disagreement among citizens. Meanwhile, they resolve their disputes by the very democratic procedure they claim to supersede - majority vote. We never hear about the potential dangers of a tyrannous judicial majority, yet it is far more likely than among legislatures or the electorate. Among judges a majority vote is simply a closure device among a haphazard assortment of views. It has none of the intrinsic virtues that attach to it within a democracy as a fair way of showing equal concern and respect to the ideas and interests of every member of the population. Moreover, a single judge's vote can alter a decision dramatically - something that rarely happens in an election or even in a legislature.

Here we come to the nub of what is wrong with constitutional judicial review - its arbitrariness. There is no adequate basis to ground the superiority of a given legal constitution and its interpreters over the rest of the citizen body. Not only may the 
process itself be inappropriate for obtaining a full and equitable consideration of the rights and interests involved, but also - and most significantly-it does not involve citizens as equals. Citizens are to be 'taught' their obligations, to employ Ms Booth's revealing term, rather than to define and enter into them on an equal basis. A key advantage of a democratic vote lies in its overcoming this arbitrary arrangement. Under majority rule each person counts for one and none for more than one. All citizens are treated equally in this respect - including judges and members of the currently incumbent government. The reason that the legislature favours certain peoples' views more than others is because more people have voted for a given party's representatives than for those of other parties. Such aggregative accounts of democratic voting are sometimes criticised as mechanical or 'statistical' (Dworkin, 1996: 364). But whatever the supposed failings of democratic decision-making, this very mechanical aspect of democracy has a decided advantage in the context of disagreement. It allows those on the losing side to hold on to their integrity. They can feel their views have been treated with as much respect as those on the winning side, counting equally with theirs in the vote, and that the winners are not thereby 'right', so that they are 'wrong', but merely the current majority. That position has been regarded as paradoxical (Wollheim 1969). Yet, any real world, and hence fallible, decision procedure involves accepting some distinction between the legitimacy of the process and one's view of the result. After all, courts can and do produce results litigants or observers disagree with, but demand their judgments be accepted nonetheless because they satisfy norms of due process. The distinctiveness of the democratic process lies in its fostering precisely the political morality of mutual respect that legal constitutionalists claim they wish to promote. For it involves accepting 
one's own view as just one among others - even if one feels passionately about it, because others feel just as passionately on the other side. Democratic citizens must step back from their own preferred views and acknowledge that equal concern and respect are owed to their fellows as bearers of alternative views. It is only if we possess some such detachment that we can live on equal terms in circumstances of political disagreement by finding workable ways to agree even though we disagree.

\section{THE DEMOCRATIC CONSTITUTION}

Now, a democratic process involving majority rule may be a legitimate constitutive process - that is, a fair way for making collective decisions - but it is not necessarily a valid constitutional process - one that avoids majority tyranny by upholding individual rights and treating all in relevant ways as equal under the law. Indeed, the constitutional design of political institutions has generally assumed it is not and built in countermajoritarian checks. Here too, the influence of the American constitution casts its long shadow. The classic doctrine of the 'mixed constitution' provided the pre-democratic form of the political constitution. This idea assumed the division of society into different classes with distinct interests: namely, the people, the aristocracy and the monarchy. The crux was to achieve a balance between these three groups. The majority in this context referred to the largest group - that of the common people. Later theorists, prominent among them the authors of the Federalist Papers, then attempted to apply this thinking to a formally classless society. However, they continued to fear the propertyless had distinct interests from the rest of the population and in a democracy might use their electoral muscle to redistribute resources from the rich to the poor. A related worry concerned 
various self-interested factions who might exploit populist policies to obtain power and pursue their own ends. They saw counter-majoritarian measures, which mainly reworked the older ways of dispersing power, as necessary to guard against these possibilities.

The separation of power between different branches of government was an adaptation of the 'mixed constitution' and the attempt to balance the interests of different social groups (Bellamy, 1996). It was supposed to prevent either the majority group in the legislature or a populist executive being in a position to enact laws in their own interest. Bicameralism offered a further check, with the second chamber supposedly representing both longer term interests and, within a federal system, those of different regions. Yet, a prime effect of such mechanisms has been to multiply veto points and produce imbalances that favour vested interests and privileged positions (McGann, 2004). For they favour the status quo and those who benefit from it. As such, they have invariably had a regressive impact. For example, in the US it enabled the state and federal courts to strike down some 150 pieces of labour legislation between 1885 and 1935 of an analogous kind to those passed by western democracies free from such constraints over roughly the same period. Change only came when chronic economic depression and war allowed a hugely popular President with a large legislative majority to overcome judicial and other barriers to social reform.

Of course, opponents of such social legislation rarely argue on self-interested grounds. Rather, they contend they are upholding the property rights necessary for a dynamic economic system that it is in the public interest to keep. Hence the need to give these rights constitutional protection against myopic majoritarian calls for redistribution. However, proponents of social justice mount a similarly principled case that also appeals 
to arguments for economic efficiency, and seek likewise to constitutionalise social rights. Such debates are a prime source of 'reasonable disagreement' in contemporary politics indeed, the ideological divide between Left and Right provides the principal political cleavage in most democracies. The enduring character of this division arises to a large degree from genuine difficulties in specifying what a commitment to liberty and equality actually entails in terms either of social arrangements or particular policy recommendations. Views on both tend to be subject to a certain amount of guess work and constant updating in the light of experience and evolving circumstances. Constitutionalising either position simply biases the debate towards the dominant vie w of the time, usually that of the then hegemonic groups, by constraining the opportunities for critique and the equal consideration of interests.

By contrast, we have seen how a prime rationale of democracy lies in its enshrining political equality by providing fair procedures whereby such disagreements can be resolved. That this is also a constitutional process arises from the way it embodies the old notion of balance in a new and dynamic form, so that affected individuals are moved to abide by the classical injunction of 'hearing the other side' that lies at the heart of procedural accounts of justice (Hampshire 1999: 21). This requirement calls for the weighing of the arguments for and against any policy, and the attempt to balance them in the decision. It also involves opportunities to contest and improve policies should they fail to be implemented correctly, have unanticipated consequences - including failure, or cease to be appropriate due to changed circumstances. Finally, it renders rulers accountable and responsive to the ruled, preventing them seeing themselves as a class 
apart with distinct interests of their own. These qualities offer a procedural approach to showing individuals equal concern and respect.

All three senses of balance are present in majority voting in elections between competing parties. This mechanism promotes the equal weighing of arguments in order to show equal respect, produces balanced decisions that demonstrate equal concern, and involves counter-balances that offer possibilities for opposition and review, thereby providing incentives for responsive and improved decision-making on the part of politicians. I have already remarked how one person, one vote treats people as equals. In May's terms (1952), it is anonymous, neutral and positively responsive as well as decisive. However, notorious problems potentially arise with three or more options. As Arrow and his followers have shown, in these circumstances any social ordering of individual preferences, not least majority rule, is likely to be arbitrary. Yet, though logically possible, cycles and the resulting problems of instability, incoherence or manipulation turn out to be rare (Mackie, 2003). The range of options considered by both the electorate and legislatures is considerably fewer than the multifarious rankings people might offer of the total range of policy issues. Instead, they choose between a small number of party programmes. Parties and the ideological traditions they represent have the effect of socialising voters so that their preferences resemble each other sufficiently for cycles to be unusual and eliminable by relatively simple decision rules that help voters select the package of policies containing their most favoured options. And though voting systems may produce different results, the choice between them need not be regarded as arbitrary - all the realistic contenders can make legitimate claims to fairness 
and possess well known advantages and disadvantages that make them suited to different social circumstances.

It might be objected that these effects result from elites controlling party agendas, making them instruments of domination. Yet party programmes have been shown to alter over time in ways frequently at variance with the interests of entrenched social and economic groups. To a remarkable degree, election campaigns determine policy, with party discipline rendering politicians far more like electoral delegates than trustees (Klingermann, Hofferbert and Budge, 1994). Party competition also plays a key role in the production of balanced decisions. To win elections, parties have to bring together broad coalitions of opinions and interests within a general programme of government. Even under PR systems, where incentives may exist for parties to appeal to fairly narrow constituencies, they need to render their programmes compatible with potential coalition partners to have a chance of entering government. In each of these cases, majorities are built through the search for mutually acceptable compromises that attempt to accommodate a number of different views within a single complex position. Such compromises are sometimes criticised as unprincipled and incoherent, encouraging 'pork barrel politics' in which voters get bought off according to their ability to influence the outcome rather than the merits of their case. Despite a system of free and equal votes, some votes can count for more than others if they bring campaigning resources, are 'deciding' votes, or can ease the implementation of a given policy. However, different political resources tend to be distributed around different sections of the community, while their relative importance and who holds them differs according to the policy. Democratic societies are also invariably characterised by at least some cross-cutting 
cleavages that bind different groups together on different issues. Many of these bonds relate not to interests in the narrow economic sense, but shared values. After all, the purely self-interested voter would not bother going to the polls.

These features of democratic politics create inducements to practice reciprocity and so support solidarity and trust between citizens. Lying mid-way between selfinterested bargaining and ethical universalism, reciprocity involves an attempt to accommodate others within some shareable package of policies. This attempt at mutual accommodation does not produce a synthesis or a consensus, since it contains many elements those involved would reject if taken in isolation. Rather, it responds to the different weights voters place on particular policies or dimensions of a problem - either allowing trade-offs to emerge, or obliging those involved to adopt a mutual second best when too many aspects are in conflict. In circumstances of reasonable disagreement, such compromises recognise the rights of others to have their views treated with equal concern as well as respect. They legitimately reflect the balance of opinion within society (Bellamy, 1999: Chs 4 and 5).

Naturally, some groups may still feel excluded or dissatisfied, while the balance between them can alter as interests and ideals evolve with social change. The counterbalances of party competition come in here. The presence of permanent opposition and regular electoral contests means that governments will need to respond to policy failures and alterations in the public mood brought about by new developments. The willingness of parties to alter their policies is often seen as evidence of their unprincipled nature and the basically self-interested motives of politicians and citizens alike. However, this picture of parties cynically changing their spots to court short term popularity is belied by 
the reality. Leap-frogging is remarkably rare, not least because they and their core support retain certain key ideological commitments to which changes in policy have to be adapted. Nevertheless, that parties see themselves as holding distinctive rather than diametrically opposed views renders competition effective, producing convergence on the median voter, which is generally the Condorcet winner (Ordeshook, 1986: 245-57). By contrast, the separation of powers removes (in the case of courts) or weakens (in the case of elected bodies) such incentives, for the various branches of government can hardly be viewed as competing. The ability of courts particularly to isolate themselves from public pressure is often seen as an advantage. But it can also lead to blame shifting as responsibility gets divided, with each branch seeking to attribute the political and financial costs of their decisions to one or more of the others (Brennan and Hamlin, 1994).

Of course, the more polarised social divisions are, the harder it will be for such mechanisms to work. The danger of majority domination increases in societies deeply divided on ethnic, religious or linguistic lines. In these conditions, democratic arrangements generally require measures to secure minority influence. Strictly speaking, many of these need not be considered as anti-majoritarian. Enhancing proportionality simply represents a fairer way of calculating the majority than plurality systems, say, while greater regional autonomy for territorially concentrated minorities merely devolves decision making over certain policies to a different majority. Where it proves necessary to go beyond proportionality by giving minorities a veto or an equal or much inflated role in executive power or federal law making, the danger arises that the checks and balances arising from party competition get eroded. The elites of the different social segments gain 
an interest in stressing the particular divisions they reflect over other differences or any shared concerns, with debates about the organisation of government undermining accountability for its conduct. However, a legal constitution is unlikely to counter such tendencies. It will either reproduce them, its legitimacy depending on the degree to which the court and constitution reflect the main political divisions, or it will rightly or wrongly become identified with the dominant elite who have the greatest interest in preserving unity.

What about 'discreet and insular minorities'? As Mark Tushnet (1999: 159) counsels 'we have to distinguish between mere losers and minorities who lose because they cannot protect themselves in politics.' Within most democracies, the number of minorities incapable of allying with others to secure a degree of political influence is very small. However, there are undeniably certain groups, such as asylum seekers or the Roma, who have little or no ability to engage in politics. In such cases, the necessity for legal constitutional protection might appear undeniable. Even here, though, three caveats are in order. First, such protection will only be necessary if it is assumed that: a) such minorities are at risk from widespread prejudice from a majority of the population and their elected representatives, and b) the judiciary are free from such prejudices. However, most defenders of legal constitutionalism accept it is unlikely to have much effect unless the rights it enshrines express a common ideology of the population about the way their society should be governed (Raz, 1998: 154). And as Nazi Germany reveals, widespread popular prejudices against a minority are likely to be shared by a significant proportion of the ruling elite, including the legal establishment and where they are not the judiciary is unlikely to be able to withstand sustained popular and governmental pressure. So judicial 
review will only afford protection where there is a temporary lapse from commonly acknowledged standards. Such cases - which need to be balanced against those where the judiciary may similarly fall short - do not offer a basis for a general defence of strong judicial review. Yet, it may be difficult to distinguish the exceptional case, where it may be legitimate and beneficial for the judiciary to intervene, from the standard cases where it is not.

Second, as I noted, when the judiciary does intervene it does so in limited ways. Courts naturally view even constitutional questions from the narrow perspective of legality and formal instances of discrimination or unfairness. As a result, their judgments risk being either too narrow or too broad. They either capture only clear ultra vires instances of executive or administrative discretion, or treat all attempts to distinguish between categories of individual as potentially discriminatory. Meanwhile, informal largely structural - exclusions arising from unequal access to various kind of resource can rarely be addressed, since these do not fit the traditional legal model of compensatory justice. Moreover, structural injustice usually requires redistributive measures that courts can only tackle through general regulatory measures. As the example of busing in the United States reveals, such instruments can be too crude - failing to consider knock on effects for other related forms of public expenditure, on say health or housing.

Finally, judicial foreclosure can impair or distort political mobilisation, yet is rarely successful in its absence. The key 'liberal' US Supreme Court decisions of the 1960s to which most contemporary legal constitutionalists refer, such as Roe v. Wade and Brown v. Board of Education, all reflected emerging national majorities. Liberal legislation in most states meant that well before Roe some 600,000 lawful abortions were 
performed a year. The narrow terms in which Roe was decided had the negative effect of 'privatising' abortion rather than treating it as a social issue requiring public funds. It has also centred political activity on capturing the court rather than engaging with the arguments of others. Likewise, the civil rights movement had far more impact than Brown. Ten years after this landmark decision no more than $1.2 \%$ of Black children attended desegregated schools in the Southern states. Desegregation only truly gained momentum following the passage by large majorities in Congress of the Civil Rights Act and the Voting Rights Act in 1964 and 1965.

Do we not need courts, though, to protect individual rights from exceptional exercises of executive discretion - most notably to protect national security in states of emergency? Once again, the belief that courts offer a calmer setting that is more attentive to rights considerations than legislatures proves misplaced. On the one hand, in both the US and the UK courts have overwhelmingly upheld such measures (Ewing, 2004), with the Supreme Court being substantially more likely to curtail rights and civil liberties during such crises than when peace prevails (Epstein et al, 2005). Not withstanding the questionable justifiability of such measures as the internment of Japanese Americans during the Second World War or the ban on the Communist Party during the Cold War, the judges deferred to executive authority. Yet, in many respects it would be hard for them to do otherwise - they neither have access to the intelligence nor the responsibility for assessing such risks. By and large they have concentrated on the procedural propriety of such measures. On the other hand, though, elected legislatures have not been as unquestioning as is often assumed. Party loyalty frequently breaks down in such cases precisely because representatives acknowledge issues of constitutional principle may be 
at stake. For example, as with counter-terrorism measures in Northern Ireland, the UK parliament imposed a sunset clause on the Anti-terrorism, Crime and Security Act 2001, and the even more draconian measures introduced by the Terrorism Bill following the London bombings of 7 July 2005 led to Tony Blair's first defeat in the Commons since coming to power in 1997. Far from these measures attracting populist support, there is every indication that his policy has become an electoral liability.

\section{CONCLUSION}

Not just legal theorists but also political theorists have tended to ignore and even denigrate the qualities of 'actually existing democracy'. Instead, they advocate a deliberative view of democracy, governed by similar considerations of public reason to those they believe should be adopted by constitutional courts. Moreover, inspired by the largely pre-democratic constitutional assumptions of the American founders, they seek to achieve this result by a range of anti-democratic checks and balances designed to guard against a mythical tyranny of the majority - not least rights-based, constitutional judicial review. However, the check this procedure imposes on majoritarian decision making risks undermining political equality, distorts the agenda away from the public interest, and entrenches the privileges of dominant minorities and the domination of unprivileged ones. Consequently, such a legal constitutionalism produces rather than constrains arbitrary rule, detracts from the rights protection of weak minorities, and damages the rule of law in both the formal and the substantive senses of treating all as equals. By contrast, the workings of actually existing democracies promote the constitutional goods of rights and the rule of law. Party competition and majority rule on the basis of one 
person one vote uphold political equality and institutionalise mechanisms of political balance and accountability that provide incentives for politicians to attend to the judgements and interests of those they govern and to recruit a wide range of minorities into any ruling coalition. The moral is plain - American style judicial review damages both democracy and constitutionalism. Rather than constraining democracy with written constitutions and greater judicial oversight, attention should be made to improving democratic processes through such measures as reformed electoral systems and enhanced parliamentary scrutiny.

\section{Notes}

${ }^{1}$ As well as being aired at APSA, longer versions of this paper served as the $4^{\text {th }}$ Martin Hollis Memorial Lecture and my inaugural lecture as UCL's first Professor of Political Science. I am grateful to the audiences on all three occasions for their helpful comments.

\section{References}

Bellamy, R (1996) 'The Political Form of the Constitution: The Separation of Powers, Rights and Representative Democracy', Political Studies, 44: 436-56

Bellamy, R. (1999) Liberalism and Pluralism: Towards a Politics of Compromise. London: Routledge.

Bellamy, R. (2007) Political Constitutionalism: A Republican Defence of the Constitutionality of Democracy. Cambridge: Cambridge University Press.

Booth, C. (2005) 'The Role of the Judge in a Human Rights World', Speech to the Malaysian Bar Association, 26 July. 
Brennan, G. and Hamlin, A. (1994) 'A Revisionist View of the Separation of Powers', Journal of Theoretical Politics, 6, 345-68

Dworkin, R. (1996) 'Introduction: The Moral Reading and the Majoritarian Premise', Freedom's Law: The Moral Reading of the American Constitution, Oxford: Oxford University Press, 1996, pp. 1-38.

Ely, J. H. (1980) Democracy and Distrust: A Theory of Judicial Review, Cambridge Ma: Harvard University Press.

Epstein, L., Ho, D. E., King, G. and Segal, J.A. (2005) 'The Supreme Court During Crisis: How War Affects Only Non-War Cases', New York University Law Review, 80: $1-116$

Ewing, K. (2004) 'The Futility of the Human Rights Act', Public Law, 829-52.

Hampshire, S. (1999) Justice is Conflict. Duckworth, London.

Klingermann, H-D ; Hofferbert, R. I. and Budge, I. (1994) Parties, Policies and Democracy. Westview Press, Oxford.

Mackie, G. (2003) Democracy Defended. Cambridge University Press, Cambridge Maddox , G. (1982) 'A Note on the Meaning of `Constitution' ', American Political Science Review, 76: 805-809

May, K. (1952) ‘A Set of Independent, Necessary and Sufficient Conditions for Simple Majority Decision'. Econometrica, 10: 680-84

McGann, A. J. (2004) 'The Tyranny of the Supermajority: How Majority Rule Protects Minorities'. Journal of Theoretical Politics 16, 53-77.

Morris-Jones, W. H. (1965) ‘On Constitutionalism’, American Political Science Review, 59: $439-440$ 
Ordeshook, P. C. (1986) Game Theory and Political Theory Cambridge University Press, Cambridge.

Rawls, J. (1993) Political Liberalism. Columbia University Press, New York

Raz, J. (1998) 'On the Authority and Interpretation of Constitutions' in L. Alexander (ed), Constitutionalism: Philosophical Foundations, Cambridge: Cambridge University Press, pp152-93.

Sartori, G. (1962) 'Constitutionalism: A Preliminary Discussion', American Political Science Review, 56: 853-864

Tushnet, M. (1999) Taking the Constitution Away from the Courts. Princeton University Press, Princeton.

Waldron, J. (1999) Law and Disagreement, Oxford: Oxford University Press.

Wollheim, R. (1969) 'A Paradox in the Theory of Democracy'. In P. Laslett and W G Runciman (eds), Philosophy, Politics and Society. Second Series. Blackwell, Oxford. 


\begin{abstract}
About the author
Richard Bellamy is Professor of Political Science and Director of the School of Public Policy, University College London (UCL), University of London. Recent publications include Liberalism and Pluralism: Towards a Politics of Compromise (Routledge, 1999), Rethinking Liberalism (Continuum, 2000, 2005) and (as co-editor) The Cambridge History of Twentieth Century Political Thought (CUP, 2003), Lineages of European Citizenship (Palgrave, 2004) and Making European Citizens (Palgrave, 2006). His Political Constitutionalism: A Republican Defence of the Constitutionality of Democracy was published by Cambridge University Press in 2007.
\end{abstract}

\title{
Key quotes:
}

Page 3- 'misconceptions about both constitutionalism and democracy ... stem from the idealisation of the Constitution of the United States by distinguished American legal and political philosophers' 